\title{
Magnetic Properties of Cherts from the Basque-Cantabrian Basin and Surrounding Regions: Archeological Implications
}

\section{OPEN ACCESS}

Edited by:

Luigi Jovane,

Instituto Oceanográfico da

Universidade de São Paulo, Brazil

Reviewed by:

Eric Font,

University of Lisbon, Portugal

Greig A. Paterson,

Chinese Academy of Sciences, China

Qingsong Liu,

Chinese Academy of Sciences, China Giancarlo Scardia

Universidade Estadual Paulista, Brazil

*Correspondence:

Juan C. Larrasoaña jc.larra@igme.es

${ }^{\dagger}$ Present Address:

Juan C. Larrasoaña

Institute of Earth Sciences Jaume

Almera, ICTJA-CSIC, Lluís Solé i Sabarís s/n, 08028 Barcelona, Spain

Specialty section:

This article was submitted to Geomagnetism and Paleomagnetism,

a section of the journal Frontiers in Earth Science

Received: 11 January 2016 Accepted: 22 March 2016 Published: 13 April 2016

Citation:

Larrasoaña JC, Beamud E, Olivares M, Murelaga X, Tarriño A, Baceta Jl and Etxebarria N (2016) Magnetic Properties of Cherts from the Basque-Cantabrian Basin and Surrounding Regions: Archeological Implications. Front. Earth Sci. 4:35. doi: 10.3389/feart.2016.00035

\begin{abstract}
Juan C. Larrasoaña ${ }^{1,2 * \dagger}$, Elisabet Beamud ${ }^{2}$ Maitane Olivares $^{3}$, Xabier Murelaga $^{4}$, Andoni Tarriño ${ }^{5}$, Juan I. Baceta ${ }^{4}$ and Nestor Etxebarria ${ }^{3}$

${ }^{1}$ Unidad de Zaragoza, Instituto Geológico y Minero de España, Zaragoza, Spain, ${ }^{2}$ Paleomagnetic Laboratory CCiTUB-CSIC Institute of Earth Sciences Jaume Almera, Barcelona, Spain, ${ }^{3}$ Departamento de Química Analitica, Universidad del País Vasco, Bilbao, Spain, ${ }^{4}$ Departamento de Estratigrafía y Paleontología, Universidad del País Vasco, UPV/EHU, Bilbao, Spain, ${ }^{5}$ CENIEH-National Research Center on Human Evolution, Burgos, Spain
\end{abstract}

We present the first rock magnetic study of archeologically-relevant chert samples from the Basque-Cantabrian basin (BCB) and surrounding regions, which was conducted in order to test the usefulness of non-destructive magnetic properties for assessing chert quality, distinguishing source areas, and identifying heated samples in the archeological record. Our results indicate that the studied BCB cherts are diamagnetic and have very low amounts of magnetic minerals. The only exception is the chert of Artxilondo, which has a median positive magnetic susceptibility associated with larger concentrations of magnetic minerals. But even in this case, the magnetic susceptibility is within the lower range of other archeologically-relevant cherts elsewhere, which indicates that the studied BCB cherts can be considered as flint. The similar median values for all magnetic properties, along with their associated large interquartile ranges, indicates that rock magnetic methods are of limited use for sourcing different types of flint except in some specific contexts involving the Artxilondo flint. With regards to the identification of chert heating in the archeological record, our results indicate only a minor magnetic enhancement of BCB natural flint samples upon heating, which we attribute to the low amount of non-silica impurities. In any case, the diamagnetic behavior of most BCB natural flints, along with the local use only of the Artxilondo type, suggests that any flint tool within the core of the BCB with positive magnetic susceptibility values is likely to have been subjected to heating for improving its knapping properties. Further studies are necessary to better identify the type, origin and grain size of magnetic minerals in BCB natural flints, and to apply non-destructive magnetic properties to flint tools in order to identify the use of heat treatment in the BCB archeological record.

Keywords: environmental magnetism, chert, flint knapping, archeology, Basque-Cantabrian basin

\section{INTRODUCTION}

Magnetic minerals are virtually present in all types of rock samples, albeit in concentrations as low as few parts per million (see Thompson and Oldfield, 1986; Verosub and Roberts, 1995; Dunlop and Özdemir, 1997; Evans and Heller, 2003; Liu et al., 2012). Despite of these low concentrations, 
equipment available at most paleomagnetic laboratories enable a very sensitive way for rapidly identifying different types of magnetic minerals as well as establishing relative variations in their concentration and grain size. Since these properties are controlled by physico-chemical conditions prevailing during formation and accumulation of magnetic minerals, environmental magnetic techniques can be used for discriminating different rock samples on their basis of their rock magnetic properties. The advantage of environmental magnetic techniques is that most of them are non-destructive and can be combined with standard geochemical and geophysical tools.

Environmental magnetic properties have been successfully used for identifying and classifying different types of natural materials such as meteorites (e.g., Folco et al., 2006). They have been also applied in archeology for discriminating obsidian and other raw material of archeological interest such as chert and flint (McDougall et al., 1983; Tarling, 1990; Church and Caraveo, 1996; Borradaile et al., 1998; Thacker and Ellwood, 2002; Sternberg, 2008). Studies focused on chert samples have already shown the usefulness of rock magnetic properties to establish the degree of chert purity and to assess the provenance of some chert types (see Borradaile et al., 1993, 1998; Thacker and Ellwood, 2002; Sternberg, 2008). Some of these papers have also noticed the important changes in rock magnetic properties of chert samples upon heating (Borradaile et al., 1993, 1998). This has important implications, because thermal treatment of chert improves its flaking properties (by helping fractures to propagate within the material, Domanski and Webb, 1992) and its identification can be used to constrain variable technological capabilities. Identification of burnt chert is important also because it can provide reliable paleointensity determinations (Kapper et al., 2015). In order to further examine the potential of environmental magnetic parameters for assessing chert quality and distinguishing source areas, new studies of archeologically relevant regions are necessary. In this work we provide the first report of non-destructive environmental magnetic properties of raw chert samples collected in outcrops from the BasqueCantabrian, western Ebro and Aquitanian basins, and the western Pyrenees (Figure 1), a region characterized by a large number of archeological sites (see Tarriño et al., 2015). Previous studies of this kind in Spain are restricted to short publications and meeting presentations in which the magnetic properties of chert are not discussed in detail (Larrasoaña et al., 2010; Ortega et al., 2016). We have also made some heat treatment experiments in order to establish the magnetic properties of chert after heating and to explore the possibility of identifying heated samples in the archeological record.

\section{MATERIALS AND METHODS}

Rock magnetic properties were measured for 71 raw chert samples collected from upper Cretaceous to Miocene marine (deep and shallow settings) and continental (lacustrine) sedimentary rocks from the Basque-Cantabrian basin (BCB) and the surrounding areas of the eastern part of the Aquitanian basin, the eastern Ebro basin, and the western Pyrenees
(Figures 1, 2). In the following, we will refer to the studied area as the $\mathrm{BCB}$ to account for the relevance and central location of this area in the studied dataset. The studied cherts appear as irregular, ellipsoidal or botryoidal nodules embedded within marls, limestones and turbidite layers, although in some cases some laminar and massive-brechoid varieties are also found (Figure 3; Tarriño et al., 2015). These cherts are not related to the primary accumulation of silica-producing organisms such as radiolarians, sponges or diatoms, but to a secondary (early diagenetic) replacement of the host rock by dissolved silica that precipitates in the form of microcrystalline quartz (Olivares et al., 2009; Tarriño et al., 2015). Cherts formed in deep marine (abyssal) sedimentary environments (e.g., Artxilondo, Kurtzia, Bidache types) are composed mainly of $\alpha$-quartz, whereas those formed in shallow marine settings (e.g., Urbasa) and continental environments (e.g., Ablitas, Loza, Treviño) are composed of both $\alpha$-quartz and moganite (Olivares et al., 2009). The early diagenetic origin of these chert types is attested by the occurrence

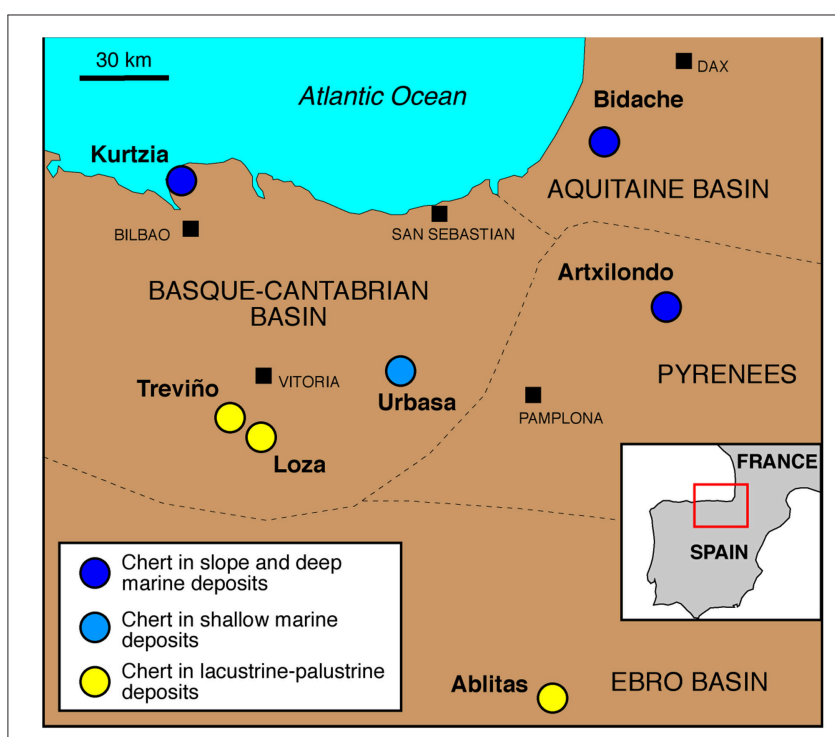

FIGURE 1 | Synthetic map of the Basque-Cantabrian basin and surrounding regions with the location of the chert types studied in this work (after Tarriño et al., 2015).

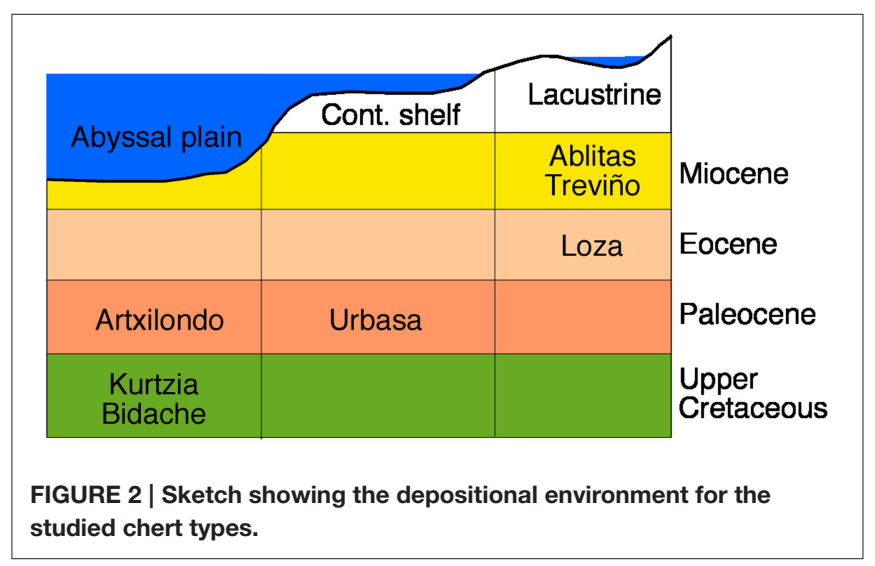



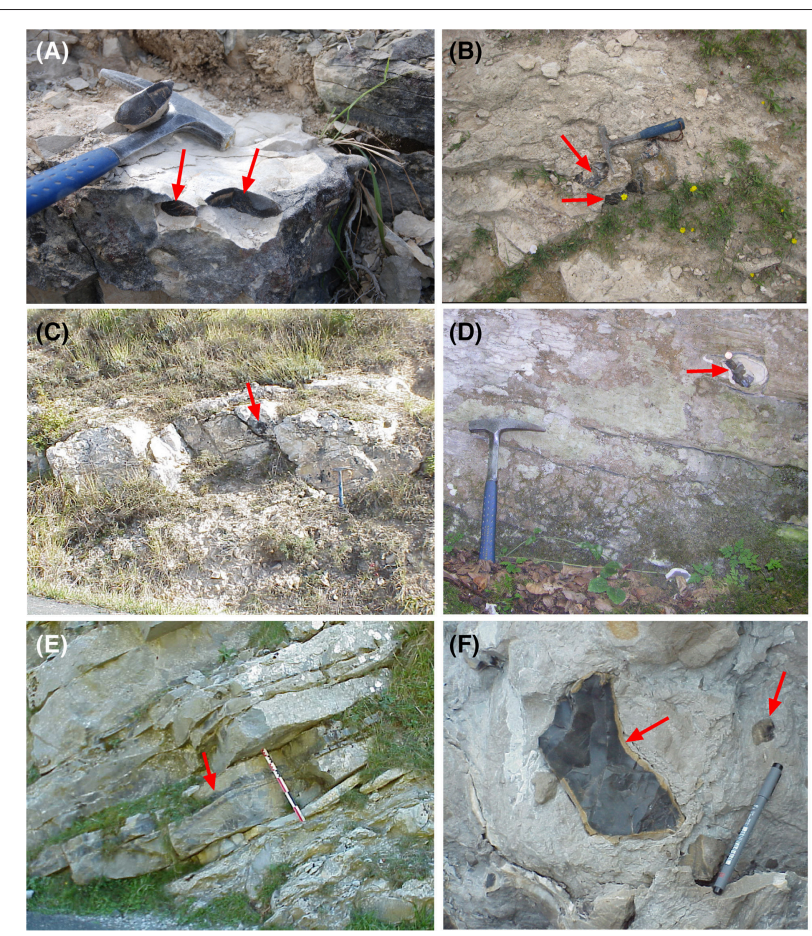

FIGURE 3 | Field examples of the different chert types studied in this work. (A) Treviño; (B) Ablitas; (C) Loza; (D) Urbasa; (E) Artxilondo; (F) Kurtzia. Red arrows indicate the positions of chert nodules or accumulations. Note the nodular appearance of chert in all cases but in (E), where laminar chert is found.

of some faints of microfossils embedded within the chert, which results in minor amounts $(<2 \%)$ of calcium carbonate and organic matter. Fossils embedded occasionally within chert include planktonic foraminifera in the case of deep marine types (Artxilondo, Kurtzia, Bidache types), large benthic formanifera and echinoderms in the case of shallow marine types (Urbasa), and gastropods, ostracodes, and algal laminations in the case of continental types (Ablitas, Loza, Treviño; see Olivares et al., 2009; Tarriño et al., 2015). Chert samples were collected from their host rocks in 8 localities (Urbasa cherts were sampled at two sites). At every site, 5 to 9 nodules (one sample per nodule or individual accumulation) were taken.

The studied cherts belong to seven of the most relevant chert types used since the Paleolithic in an archeologically important area that includes the regions of Asturias, Cantabria, Basque Country, Navarra (in Spain) and Pyrénées Atlantiques (in France) (Table 1; see Tarriño et al., 2015 for a detailed account). Of these chert types, five of them are labeled as "widespread" ("tracer" in Tarriño et al., 2015) due to their high knapping quality and widespread distribution through the studied area. The Kurtzia chert is present in most Paleolithic sites in the region, including Las Caldas (Asturias), Altamira (Cantabria), Antoliñako Koba (Basque Country), and Alkerdi (Navarra), among many others. The Bidache chert is the main chert identified in Isturitz (Pyrénées Atlantiques) and is also relevant in Spanish sites such as Las Caldas (Asturias), Altamira
(Cantabria), Antoliñako Koba (Basque Country), and Alkerdi (Navarra). Another commonly used chert is the Urbasa type, which is found in sites such as Isturitz (Pyrénées Atlantiques), Las Caldas (Asturias), Altamira (Cantabria), Mugarduia and Portugain (Navarra), and Antoliñako Koba (Basque Country). The Treviño chert is also found throughout the $\mathrm{BCB}$ region, at sites such as Las Caldas (Asturias), Altamira (Cantabria), Antoliñako and Labeko caves (Basque Country), Mugarduia and Portugain (Navarra), and Isturitz (Pyrénées Atlantiques). Since the Neolithic, the Ablitas chert is widely used throughout the $\mathrm{BCB}$ region too. In contrast to these widespread chert types, the other chert types are less used due to their lower knapping qualities. The Loza type has a more restricted use (in sites such as Mendandia and Kanpanoste, Basque Country) and is considered of regional importance (Tarriño et al., 2015). The Artxilondo chert has an even more restricted use, so that it has been found only in the neighboring Aizpea site (Navarra) and is considered of local importance (Tarriño et al., 2015). Extraction workshops appear associated with at least four of these chert types, namely Kurtzia (Kurtzia Prehistoric Station, Barandiarán et al., 1960), Urbasa (Mugarduia Sur; Barandiarán et al., 2013), Bidache (Mouguerre megabreccia; Normand, 2002) and Treviño (Pozarrate; Tarriño et al., 2014; see Figure 1).

Decorticated (e.g., without the altered rim) chert samples were cut in cubes that were, in turn, mounted on standard paleomagnetic plastic cubes of $2 \times 2 \times 2 \mathrm{~cm}$. Rock magnetic measurements were performed at the Paleomagnetic Laboratory of the IES Jaume Almera (CCiTUB-ICTJA CSIC), and include the low field magnetic susceptibility $(\chi)$ and two isothermal remanent magnetizations applied at $0.3 \mathrm{~T}$ (IRM@0.3T) and 1.2 T (IRM@1.2T). $\chi$ was measured with a Kappabridge KLY2 (Geofyzica Brno) susceptibility bridge using a field of 0.1 $\mathrm{mT}$ at a frequency of $470 \mathrm{~Hz}$. IRM@0.3T and IRM@1.2T were produced using a IM10-30 (ASC Scientific) pulse magnetizer and were measured using a SRM755R (2G Enterprises) three-axes cryogenic superconducting rock magnetometer. All magnetic properties were normalized by the weight of the samples. We have used different magnetic properties and interparametric ratios to determine relative variations in the type and concentration of magnetic minerals (Thompson and Oldfield, 1986; Verosub and Roberts, 1995; Evans and Heller, 2003; Liu et al., 2012). $\chi$ is typically used as a first order indicator for the concentration of ferromagnetic (s.l.) minerals, but it is also affected by other common rock constituents such as diamagnetic (e.g., quartz and most carbonates) and paramagnetic (e.g., clays, feldspars) minerals. A better proxy for the concentration of ferromagnetic (s.l.) minerals is IRM@1.2T (Thompson and Oldfield, 1986). Then, the forward S ratio (defined as IRM@0.3T/IRM@1.2T, see Kruiver and Passier, 2001), can be used to indicate the relatively contribution of low (e.g., magnetite) vs. high (hematite and goethite) coercivity minerals.

Heat treatment experiments were later conducted with the same set of chert samples using a paleomagnetic furnace MMTD80 (Magnetic Measurements). In order to simulate conditions likely available for ancient humans, samples were heated with a rate of $30^{\circ} \mathrm{C}$ per min to a maximum temperature of $450^{\circ} \mathrm{C}$ 
TABLE 1 | Median values and associated interquartile ranges (IQR) for magnetic properties of BCB chert types measured in this study.

\begin{tabular}{|c|c|c|c|c|c|c|c|c|c|c|}
\hline Chert type & $\chi\left(10^{-9} \mathrm{~kg} / \mathrm{m}^{3}\right)$ & $\operatorname{IQR}\left(10^{-10}\right)$ & $\begin{array}{c}\text { IRM@1.2T } \\
\left(10^{-6} \mathrm{Am}^{2} / \mathrm{kg}\right)\end{array}$ & IQR $\left(10^{-6}\right)$ & S ratio & IQR & $\mathbf{N}$ & $\begin{array}{c}\chi \text { heated } \\
\left(10^{-9} \mathrm{~kg} / \mathrm{m}^{3}\right)\end{array}$ & $\operatorname{IQR}\left(10^{-9}\right)$ & $\mathbf{N}$ \\
\hline Treviño & -4.54 & 1.58 & 3.24 & 2.5 & 0.93 & 0.04 & 10 & 1.9 & 5.19 & 9 \\
\hline Ablitas & -4.24 & 8.05 & 1.87 & 5.75 & 0.93 & 0.28 & 10 & -2.76 & 3.03 & 8 \\
\hline Loza & -4.62 & 3.55 & 6.74 & 2.44 & 0.98 & 0.5 & 5 & -4.1 & 1.21 & 3 \\
\hline Urbasa 1 & -4.19 & 3.92 & 4.32 & 8.14 & 0.79 & 0.37 & 10 & -1.31 & 2.46 & 9 \\
\hline Urbasa 2 & -4.43 & 6.16 & 2.04 & 0.78 & 0.91 & 0.2 & 9 & -3.27 & 0.93 & 7 \\
\hline Artxilondo & 9.32 & 270 & 40.3 & 50.5 & 0.94 & 0.14 & 8 & 7.02 & 16.1 & 8 \\
\hline Bidache & -4.56 & 5.37 & 5.31 & 5.03 & 0.94 & 0.08 & 9 & -2.51 & 3.57 & 7 \\
\hline Kurtzia & -2.88 & 8.13 & 1.99 & 2.44 & 0.93 & 0.1 & 10 & -2.77 & 9.46 & 5 \\
\hline
\end{tabular}

(Schindler et al., 1982; Borradaile et al., 1993). After $2 \mathrm{~h}$ at this temperature, samples were left to cool down freely. Since samples broke up into small flaky fragments and shreds upon thermal treatment, the only magnetic parameter that could be reliably measured in 56 samples (after they were again weighted and mounted in new plastic cubes) was the low field magnetic susceptibility.

\section{RESULTS}

\section{Natural Chert}

The magnetic susceptibility of all the studied chert samples is negative, which indicates a dominantly diamagnetic behavior (Figure 4A; Table 1; Supplementary Table). The exceptions are one sample from the continental chert of Ablitas and most samples from the flysch-derived chert of Artxilondo, whose magnetic susceptibility reaches up to $4 \times 10^{-8} \mathrm{~m}^{3} / \mathrm{kg}$. Overall, the magnetic susceptibility of the studied cherts is much smaller than that of most chert types reported in the literature (see Thacker and Ellwood, 2002), with the exception of the Montmaneu (Spain, Ortega et al., 2016) and Ingoldmells (UK, Borradaile et al., 1998) cherts (Figure 4B).

IRM@1.2T values of up to $1 \times 10^{-4} \mathrm{Am}^{2} / \mathrm{kg}$ indicate, despite the dominant diamagnetic behavior, measurable amounts of magnetic minerals (Figure 4C). The highest IRM@1.2T intensities are found for the Artxilondo chert and for some samples of the Ablitas and Loza cherts. For the rest of the samples, IRM@1.2T values are typically lower than $2 \times 10^{-5} \mathrm{Am}^{2} / \mathrm{kg}$, which therefore indicates significantly smaller concentrations of magnetic minerals. Concerning $S$ ratios, most of the studied samples have values higher than 0.9 , although values lower than 0.9 and even lower than 0.5 are occasionally observed (Figure 4D; Table 1). The large variability of magnetic properties among samples is indicative of the presence of a non-homogeneous mixture of magnetic minerals likely characterized by different concentrations and grain sizes.

In Figure 5, magnetic susceptibility values of the studied chert samples are plotted as a function of the log of the IRM@1.2T, which enables comparison with other cherts for which both magnetic properties have been measured (Borradaile et al., 1998). Our chert samples from the BCB fall within the lower range of $\chi$ and IRM@1.2T intensities reported for chert samples from northern Ontario, and are very similar to those from Ingoldmells (UK; Borradaile et al., 1998). The exceptions are most of the samples from the Artxilondo chert and some samples from the Loza and Ablitas cherts. Overall, $\chi$ remains rather constant for log IRM@1.2T values of up to $-4.5\left(\mathrm{Am}^{2} / \mathrm{kg}\right)$ for all chert types regardless its source. Above that value, log IRM@1.2T shows a positive correlation with $\chi$ (Figure 5).

\section{Chert Heating Experiments}

After heating, the magnetic susceptibility of most studied chert samples experiences a significant increase (Figure 4A; Table 1). Nevertheless, negative values are still found for several samples, which indicate that the amount of either magnetic or paramagnetic minerals formed upon heating has not increased dramatically. Noticeably, we report a slight decrease in the median magnetic susceptibility of the Artxilondo chert upon heating. Regardless, the magnetic susceptibility of all the studied $\mathrm{BCB}$ chert samples fall well below the range of magnetic susceptibility values reported for both heated manufactured tools and laboratory-heated chert samples from $\mathrm{N}$ Ontario, which reach values exceeding 20 and $100 \times 10^{-8} \mathrm{~m}^{3} / \mathrm{kg}$, respectively (Borradaile et al., 1998).

\section{DISCUSSION}

Environmental magnetic parameters have been proposed to be useful for assessing chert quality, distinguishing source areas, and identifying heated samples in the archeological record (Borradaile et al., 1993, 1998; Thacker and Ellwood, 2002; Sternberg, 2008). We discuss our results from the BCB chert types in light of these three main issues, and consider first an additional aspect (type and origin of magnetic minerals in chert) that has not been addressed in previous archeo-magnetic studies.

For all BCB chert types, S ratios of most samples (63\%) are higher than 0.9 (Figure 4D). This indicates that magnetite is the main magnetic mineral, with some likely contribution from hematite (Thompson and Oldfield, 1986; Verosub and Roberts, 1995; Frank and Nowaczyk, 2008). The rest of the samples have $S$ ratios down to 0.1 , which points to either the dominance of hematite (Frank and Nowaczyk, 2008) or the additional occurrence of goethite (Thompson and Oldfield, 1986; Bloemendal et al., 1992; Verosub and Roberts, 1995). Keeping 


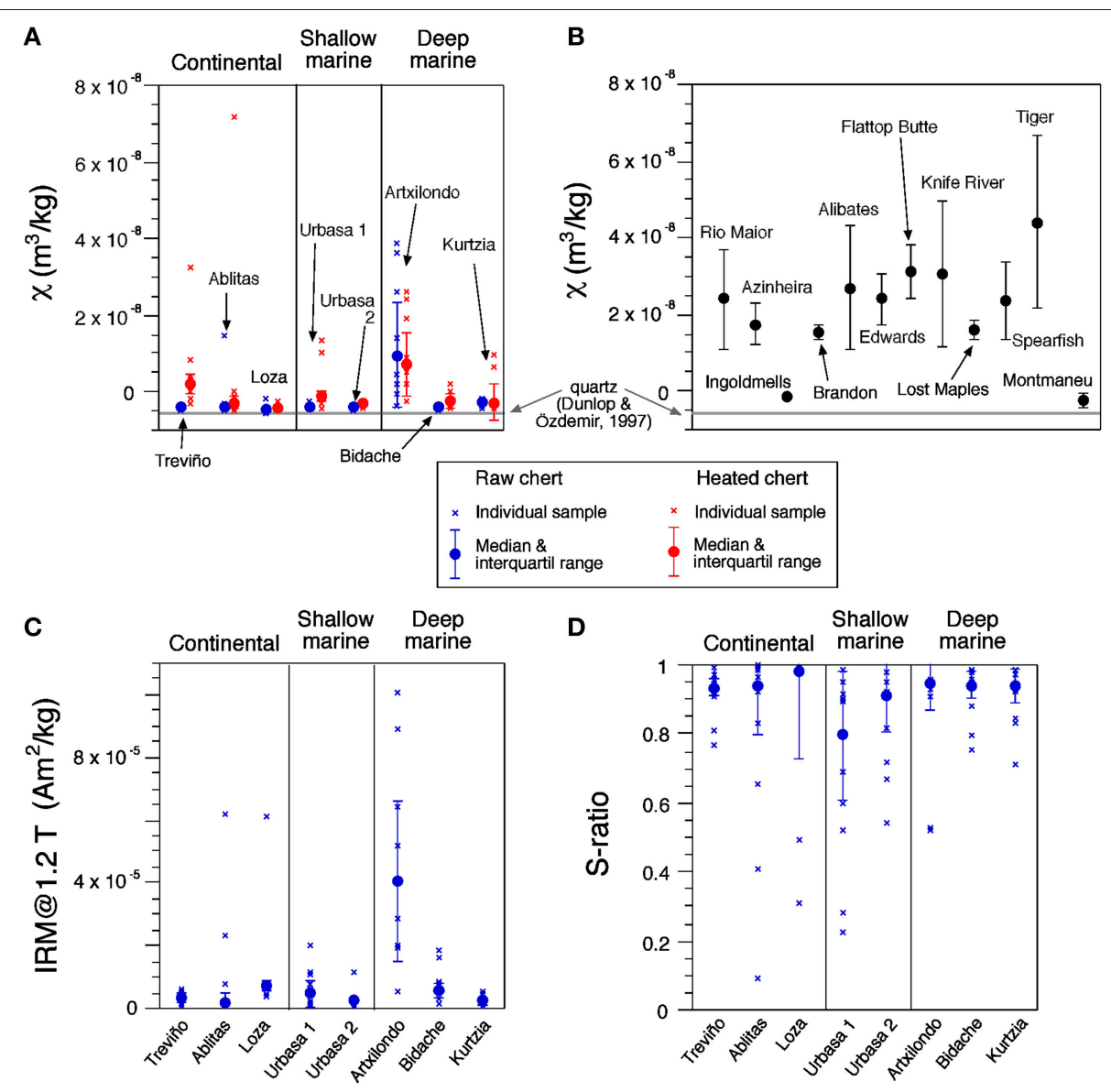

FIGURE 4 | Rock magnetic data for the studied chert samples (crosses) and their comparison with data from other chert types reported in the literature. (A) Magnetic susceptibility of raw (blue) and heated (red) chert types from the Basque-Cantabrian basin and surrounding regions; (B) Magnetic susceptibility data for other natural chert types reported in the literature. Data for Alibates, Edwards, Flattop Butte, Knife River, Spearfish, Lost Maples, Tiger (USA), Brandon (UK) and Rio Maior and Azinheira (Portugal) are after Thacker and Ellwood (2002); data for Ingoldmells (UK) are after Borradaile et al. (1998); data for Montmaneu (Spain) are after Ortega et al. (2016). (C) IRM@1.2T data for the studied natural chert types. (D) S ratios for the studied natural chert types. Whiskers indicate the interquartile ranges around the median values (large dots) but in (B), where they indicate the standard deviation around the mean values provided in the source studies.

in mind that our measurements were conducted with fresh chert samples, and therefore avoiding present-day weathering, we interpret that magnetic minerals in the studied $\mathrm{BCB}$ chert types represent primary constituents that have been enclosed in chert during early diagenetic replacement of the parent sediment by silica within concretions. Although hematite and goethite are less common in marine environments (Liu et al., 2012), their occurrence as primary minerals in deep and shallow marine rocks from the $\mathrm{BCB}$ can be explained as a result of oxidizing microenvironments or as survivors of reductive dissolution undergone typically in marine sedimentary environments (Roberts, 2015). Future rock magnetic analyses are necessary to further constrain and examine any potential controlling factor (e.g., depositional setting, age) on the magnetic mineralogy of different $\mathrm{BCB}$ chert types. It has been recently suggested that rock magnetic methods might play a role in elucidating the role of iron oxides in the formation of sedimentary chert (Roberts, 2015), which has important implications for interpreting chert as the imprint of past biological conditions (Meister et al., 2014). Florindo et al. (2003) have suggested that magnetic minerals will tend to be dissolved in sedimentary environments undergoing silica formation. In contrast, Meister et al. (2014) have recently proposed that early diagenetic formation of chert might be catalyzed by adsorption of silica on pre-existing iron oxide particles. Further rock magnetic studies of archeologicallyrelevant chert might, incidentally, help to solve this discrepancy. Thus, a comparison of the magnetic properties of chert and its host rocks (specially artificial remanences) might readily tell whether chert formation is associated with an increase (as suggested by the model of Meister et al., 2014) or a decrease (as derived from the model by Florindo et al., 2003) in the concentration of magnetic minerals within chert concretions.

Regardless the type and concentration of magnetic minerals in the different BCB chert types, the median magnetic susceptibility of the studied chert types is negative and very close to that of pure silica $\left(-0.62 \times 10^{-8} \mathrm{~m}^{3} / \mathrm{kg}\right.$; Dunlop and Özdemir, 1997). 


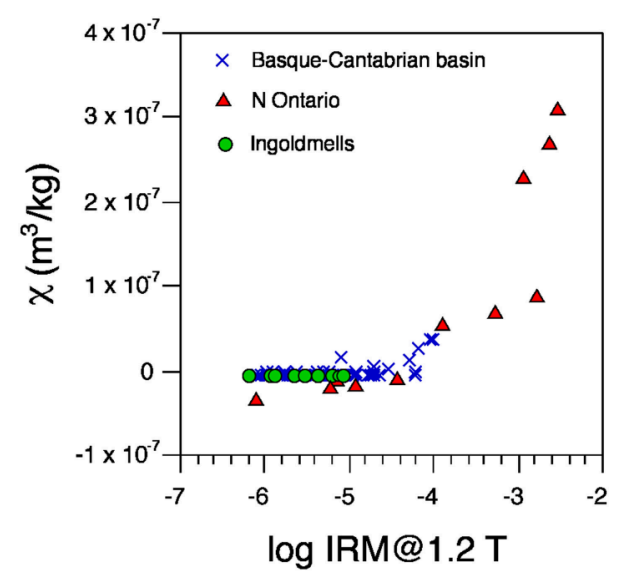

FIGURE 5 | Plot showing the log of the IRM@1.2T vs. magnetic susceptibility of the studied samples from the Basque-Cantabrian basin and their comparison with data from $\mathrm{N}$ Ontario (Canada) and Ingoldmells (UK) (Borradaile et al., 1998).

The only exception is the flysch-derived chert of Artxilondo, which has a positive median magnetic susceptibility of 9.32 $\times 10^{-9} \mathrm{~m}^{3} / \mathrm{kg}$ ) that is within the lower range of other less pure, archeologically-relevant cherts from Portugal, USA, UK and Canada (Figure 4A) (see Borradaile et al., 1998; Thacker and Ellwood, 2002). This indicates that all the studied BCB cherts, possibly including the Artxilondo type, can be considered as flint, which is the purest variety of chert (Borradaile et al., 1998). The excellent knapping properties of these flints, and their concomitant widespread use by humans inhabiting the region during the Paleolithic and Neolithic (Tarriño et al., 2015), appears to be linked with a near pure-silica composition that is signaled by a diamagnetic behavior (negative magnetic susceptibilities) and the lowest concentrations of magnetic minerals (e.g., lowest IRM@1.2T intensities). The poorer knapping properties and limited (local only) use of the Artxilondo chert appear to be linked with a higher content in impurities, which are signaled by the highest magnetic susceptibility and IRM@1.2T values of all the studied BCB dataset. Noticeably, the BCB shows an outstanding abundance and widespread distribution of highquality flint types compared with other regions, which might explain the extraordinarily rich record of lithic material found in the area.

Concerning the identification of source areas, the similar median values of most magnetic properties for the different chert types (Table 1), coupled with overlapping interquartile ranges (Figure 4), limits our capability to identify the source of the raw material found in the archeological areas but in some specific contexts. For example, the western Pyrenean region lacks chert-bearing continental and shallow-marine Paleocene units. In this region, a combination of negative magnetic susceptibility values with high IRM@1.2T intensities $\left(>2 \times 10^{-5} \mathrm{Am}^{2} / \mathrm{kg}\right)$ and low $S$ ratios $(<0.6)$ might therefore signal non-Artxilondo flint sourced tens of kilometers further west. Similarly, any Paleolithic flint tools within the core of the BCB with low $S$ ratios $(<0.7)$ likely correspond with either Urbasa or Loza flints, since the Ablitas type was not yet used in the region and the Artxilondo flint is of local use in the western Pyrenees only. In any case, it appears that non-destructive magnetic properties such as the ones measured here need to be treated with caution for an initial screening of different flint types that needs to be contrasted with other analytical methods (see Olivares et al., 2013).

The last issue under consideration is that of using magnetic properties to identify heat treatment of chert in the archeological record. Our results indicate only a minor magnetic enhancement of BCB natural flint samples upon heating, so that the slight increase in magnetic susceptibility observed for most heated samples (which reach values of up to $\sim 7 \times 10^{-8} \mathrm{~m}^{3} / \mathrm{kg}$, Figure 4A) contrast with the values (ranging between 20 and $100 \times 10^{-8} \mathrm{~m}^{3} / \mathrm{kg}$ ) found, for example, for heated $\mathrm{N}$ Ontario cherts (Borradaile et al., 1998). We attribute the modest magnetic enhancement of BCB flints upon heating to the low amount of non-silica (e.g., Fe-bearing) impurities. Given such slight magnetic enhancement, it is unlikely that other magnetic properties that can be eventually measured as proxies for the concentration of magnetic minerals (e.g., IRM@1.2T) will experience the dramatic (e.g., at least ten-fold) increase observed in other heated cherts (Borradaile et al., 1993, 1998). In any case, the negative magnetic susceptibility values of most BCB natural flints, along with the local use only of the Artxilondo type (the only natural flint with positive magnetic susceptibilities), suggests that any flint tool within the core of the $\mathrm{BCB}$ with positive magnetic susceptibility values is likely to have been subjected to heating for improving its knapping properties. In the western Pyrenees, were Artxilondo-type flint is likely to be dominant, the similar magnetic susceptibility values before and after heating prevent identification of heating treatment in the archeological record.

\section{CONCLUSIONS}

The studied chert samples from the BCB are diamagnetic and have very low (but measurable) amounts of magnetic minerals (mainly magnetite and hematite) that have been enclosed in chert during early diagenetic replacement of the parent sediment by silica. This indicates that most chert types in the $\mathrm{BCB}$ can be considered as flint, which is the purest variety of chert. The only exception is the chert of Artxilondo, which has a median positive magnetic susceptibility associated with larger concentrations of magnetic minerals. But even in this case, the magnetic susceptibility is within the lower range of other archeologically-relevant cherts elsewhere. The high purity of the BCB flints, along with their widespread occurrence, might explain the extraordinarily rich record of lithic material found in the area.

The similar median values for all magnetic properties measured in this study for the different flint types, along with their associated large interquartile ranges, indicates that rock magnetic methods are of limited use for sourcing different types of flint, but in some specific contexts. Thus, the distinctively different magnetic properties of the Artxilondo flint suggests that any other flint type transported into the western Pyrenean from 
the core of the $\mathrm{BCB}$ can be easily recognized by means of nondestructive magnetic properties that will need, in any case, to be contrasted against other methods.

Concerning the use magnetic properties to identify heat treatment of chert in the archeological record, our results indicate only a minor magnetic enhancement of BCB natural flint samples upon heating, which we attribute to the low amount of nonsilica (e.g., Fe-bearing) impurities. In any case, the diamagnetic behavior of most $\mathrm{BCB}$ natural flints, along with the local use only of the Artxilondo type (the only natural flint with positive magnetic susceptibilities), suggests that any flint tool within the core of the $\mathrm{BCB}$ with positive magnetic susceptibility values is likely to have been subjected to heating for improving its knapping properties. Further studies are necessary to better identify the type, origin and grain size of magnetic minerals in $\mathrm{BCB}$ natural flints and to test the usefulness of non-destructive magnetic properties for sourcing flint tools and for identifying the presence of heated flint tools in the BCB.

\section{REFERENCES}

Barandiarán, I., Cava, A., and Aguirre, M. (2013). "El taller de sílex de Mugarduia Sur: una ocupación de Urbasa (Navarra) durante el Gravetiense," in Servicio Editorial de La Universidad del País Vasco (Vitoria).

Barandiarán, J. M., Aguirre, J. M., and Grande, M. (1960). Estación prehistórica de Kurtzia. Barrica-Sopelana (1959). Bilbao: Servicio de Investigaciones Arqueológicas de la Excma; Diputación Provincial de Vizcaya.

Bloemendal, J., King, J. W., Hall, F. R., and Doh, S. J. (1992). Rock magnetism of Late Neogene and Pleistocene deep-sea sediments: relationship to sediment source, diagenetic processes and sediment lithology. J. Geophys. Res. 97, 4361-4375. doi: 10.1029/91JB03068

Borradaile, G. J., Kissin, S. A., Stewart, J. D., Ross, W. A., and Werner, T. (1993). Magnetic and optical methods for detecting the heat treatment of chert. J. Archaeol. Sci. 20, 57-66. doi: 10.1006/jasc.1993.1004

Borradaile, G. J., Stewart, J. D., and Ross, W. A. (1998). Characterizing stone tools by rock-magnetic methods. Geoarchaeology 13, 73-91.

Church, T., and Caraveo, C. (1996). The magnetic susceptibility of southwestern obsidian: an exploratory study. North Am. Archeol. 17, 271-285. doi: 10.2190/QG75-MVKT-HE33-5VAQ

Domanski, M., and Webb, J. (1992). Effect of heat treatment on siliceous rocks used in prehistoric lithic technology. J. Archeol. Sci. 19, 601-614. doi: 10.1016/03054403(92)90031-W

Dunlop, D. J., and Özdemir, Ö. (1997). Rock Magnetism. Fundamentals and Frontiers. Cambridge: Cambridge University Press.

Evans, M. E., and Heller, F. (2003). Environmental Magnetism. Principles and Applications of Environmagnetics. San Diego, CA: Academic Press.

Florindo, F., Roberts, A. P., and Palmer, M. R. (2003). Magnetite dissolution in siliceous sediments. Geochem. Geophys. Geosyst. 4:1053. doi: 10.1029/2003GC000516

Folco, L., Rochette, P., Gattacceca, M., and Perchiazzi, N. (2006). In situ identification, pairing, and classification of meteorites from Antarctica through magnetic susceptibility measurements. Meteorit. Planet. Sci. 41, 343-353. doi: 10.1111/j.1945-5100.2006.tb00467.x

Frank, U., and Nowaczyk, N. R. (2008). Mineral magnetic properties of artificial samples systematically mixed from haematite and magnetite. Geophys. J. Int. 175, 449-461. doi: 10.1111/j.1365-246X.2008.03821.x

Kapper, K. L., Donadini, F., and Hirt, A. M. (2015). Holocene archeointensities from mid European ceramics, slags, burned sediments and cherts. Phys. Earth Planet. Inter. 241, 21-36. doi: 10.1016/j.pepi.2014.12.006

Kruiver, P. P., and Passier, H. F. (2001). Coercivity analysis of magnetic phases in sapropel S1 related to variations in redox conditions, including an investigation

\section{AUTHOR CONTRIBUTIONS}

JL, MO, XM, and NE contributed to the conception of study. AT, $\mathrm{MO}, \mathrm{XM}, \mathrm{NE}$, and JB provided the studied samples. JL and EB measured the magnetic properties. All the authors contributed to writing and reviewing the manuscript, and approved its submission.

\section{ACKNOWLEDGMENTS}

This study was funded by project GUI15/34 of the Universidad del País Vasco.

\section{SUPPLEMENTARY MATERIAL}

The Supplementary Material for this article can be found online at: http://journal.frontiersin.org/article/10.3389/feart. 2016.00035 of the S ratio. Geochem. Geophys. Geosyst. 2:1063. doi: 10.1029/2001GC 000181

Larrasoaña, J. C., Olivares, M., Murelaga, X., Tarriño, A., Baceta, J. I., and Etxebarria, N. (2010). "Propiedades magnéticas de sílex proveniente de la Cuenca Vasco-Cantábrica y aprte oriental de la Cuenca del Ebro: resultados iniciales e implicaciones arqueológicas," in Reunión de la Comisión de Paleomagnetismo de la SGE, MAGIBER VI (Puigcerdá), 94-95.

Liu, Q. S., Roberts, A. P., Larrasoaña, J. C., Banerjee, S. K., Guyodo, Y., Tauxe, L., et al. (2012). Environmental magnetism: principles and applications. Rev. Geophys. 50, RG4002. doi: 10.1029/2012RG000393

McDougall, J. M., Tarling, D., and Warren, S. E. (1983). The magnetic sourcing of obsidian samples from Mediterranean and Near eastern sources. J. Archaeol. Sci. 10, 441-452. doi: 10.1016/0305-4403(83)90059-6

Meister, P., Chapligin, B., Picard, A., Meyer, H., Fischer, C., Rettenwander, D., et al. (2014). Early diagenetic quartz formation at a deep iron oxidation front in the Eastern Equatorial Pacific - a modern analogue for banded iron/chert formations? Geochim. Cosmichim. Acta 137, 188-207. doi: 10.1016/j.gca.2014.03.035

Normand, C. (2002). "Les ressources en matières premiéres silceuses dans la basse vallée de l'Adour et de ses affluents," in Dir. Comportements Techniques et Économiques des Societies du Paléoloithique Supérieur dans le Context Pyrénéen, ed N. Cazals (Toulouse: Project Colletif de Recherche 2002; Service Regional de l'Archeologie de Midi-Pyrénées), 22-46.

Olivares, M., Irazola, M., Murelaga, X., Baceta, J. I., Tarriño, A., Castro, K., et al. (2013). Sourcing sedimentary cherts with archeological use through the combination of chromatographic and spectroscopic techniques. Appl. Geochem. 33, 252-259. doi: 10.1016/j.apgeochem.2013.02.020

Olivares, M., Tarriño, A., Murelaga, X., Baceta, J. I., Castro, K., and Etxebarria, N. (2009). Non-destructive spectrometry methods to study the distribution of archaeological and geological chert samples. Spectrochimica Acta Part A 73, 492-497. doi: 10.1016/j.saa.2008.12.036

Ortega, D., Terradas, X., Roqué, C., Ibáñez, J., Beamud, E., and Larrasoaña, J. C. (2016). El Sílex de la Unidad de Calizas de Montmaneu (Sector Oriental de la Cuenca del Ebro). Geogaceta. Madrid: Sociedad Geológica de España.

Roberts, A. P. (2015). Magnetic mineral diagenesis. Earth Sci. Rev. 151, 1-47. doi: 10.1016/j.earscirev.2015.09.010

Schindler, D. L., Hatch, J. H., Hay, C. A., and Brandt, R. C. (1982). Aboriginal alteration of a central Pennsylvanian jasper: analyticial and behavioural implications. Am. Antiq. 47, 526-544. doi: 10.2307/280233

Sternberg, R. S. (2008). Archaeomagnetism in Archaeometry - a semicentennial review. Archaeometry 50, 983-998. doi: 10.1111/j.1475-4754. 2008.00444.x 
Tarling, D. H. (1990). "Some uses for magnetic properties of materias in archaeological sites," in The Archaeological geology of North America, Geological Society of America, Special Volume, eds N. Lasca and J. Donahue (Boulder, CO: Geological Society of America), 597-602.

Tarriño, A., Elorrieta, I., and García-Rojas, M. (2015). Flint as raw material in prehistoric times: Cantabrian Mountains and Western Pyrenees data. Quarter. Int. 364, 94-108. doi: 10.1016/j.quaint.2014.10.061

Tarriño, A., Elorrieta, I., García-Rojas, M., Orue, I., and Sánchez, A. (2014). Neolithic flint mines of Treviño (Basque-Cantabrian Basin, Western Pyrenees, Spain). J. Lithic Stud. 1, 129-147. doi: 10.2218/jls.v1i2.1098

Thacker, P. T., and Ellwood, B. B. (2002). The magnetic susceptibility of cherts: archaeological and geochemical implications of source variation. Geoarchaeology 17, 465-482. doi: 10.1002/gea.10023

Thompson, R., and Oldfield, F. (1986). Environmental Magnetism. London: Allen and Unwin.
Verosub, K. L., and Roberts, A. P. (1995). Environmental magnetismpast, present and future. J. Geophys. Res. 100, 2175-2192. doi: 10.1029/ 94JB02713

Conflict of Interest Statement: The authors declare that the research was conducted in the absence of any commercial or financial relationships that could be construed as a potential conflict of interest.

Copyright (C) 2016 Larrasoaña, Beamud, Olivares, Murelaga, Tarriño, Baceta and Etxebarria. This is an open-access article distributed under the terms of the Creative Commons Attribution License (CC BY). The use, distribution or reproduction in other forums is permitted, provided the original author(s) or licensor are credited and that the original publication in this journal is cited, in accordance with accepted academic practice. No use, distribution or reproduction is permitted which does not comply with these terms. 